\title{
Autonomy of Community and Complementary Currencies in relation to State Law. The Eusko, the Ekhi and the Txantxi in the Basque Country
}

\author{
FLORENCIA RADELJAK*
}

Radeljak, F., 2018. Autonomy of Community and Complementary Currencies in relation to State Law. The Eusko, the Ekhi and the Txantxi in the Basque Country. Oñati Socio-legal Series [online], 8 (7), 1041-1070. Received: 15-11-2017; Accepted: 25-05-2018. Available from: https://doi.org/10.35295/osls.iisl/0000-0000-0000-0981

\begin{abstract}
The emergence of complementary and community currencies (CCCs) at a global and local scale manifests the normative innovation that characterizes these initiatives. Based on three case studies of CCCs in the Basque Country (the Ekhi, the Eusko and the Txantxi) the present paper explores the normative order of the CCCs and their processes of institutionalization through tactics of legal convergence. The level of autonomy of each CCC is systematized from a socio-legal and a socio-economic approach. The study concludes that through CCCs new institutional fields are opened which strengthen the normative and economic autonomy of the communities.
\end{abstract}

\section{Key words}

Complementary and community currencies; autonomy; normative innovation; normative orders; institutionalization; socio-legal approach; socio-economic approach

\section{Resumen}

La emergencia a nivel global y local de monedas complementarias y comunitarias (MCC) pone de manifiesto la innovación normativa que caracteriza estas iniciativas. A partir de tres estudios de casos de MCC en el País Vasco (Ekhi, Eusko y Txantxi), el presente trabajo explora los órdenes normativos de las MCC y sus procesos de institucionalización mediante tácticas de convergencia legal. Se sistematiza el nivel de autonomía de cada MCC desde un enfoque socio-jurídico y socio-económico. Se concluye que a través de las MCC se habilitan nuevos espacios institucionales que fortalecen la autonomía normativa y económica en las comunidades.

\section{Palabras clave}

Monedas Comunitarias y Complementarias; autonomía; innovación normativa; órdenes normativos; institucionalización; enfoque socio-jurídico; enfoque socioeconómico

\footnotetext{
* Sociologist-researcher, University of Buenos Aires (Santiago del Estero 1029 - Ciudad Autónoma de Buenos Aires, Argentina). Master of Art in Sociology of Law at IISL (Oñati). Email address: floradeljak@gmail.com.
} 


\section{Table of contents / Índice}

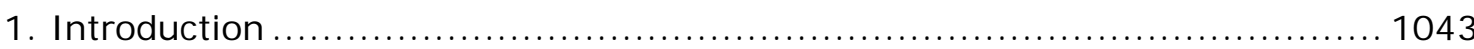

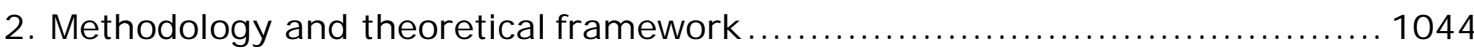

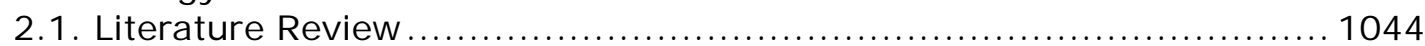

2.2. A socio-economic approach to CCCs .................................... 1046

2.3. A socio-legal approach to CCCs ....................................... 1048

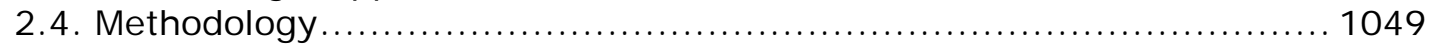

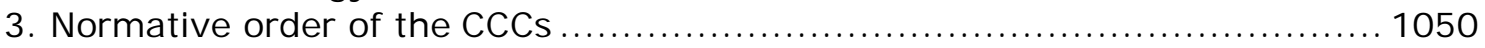

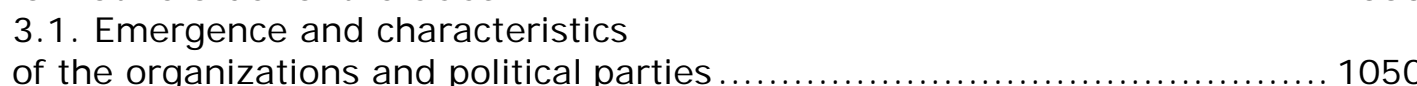

3.2. Perception of the CCC's ................................................. 1051

3.3. Perception of the relationship between the CCC's and the Community . 1051

3.4. Objectives and values............................................... 1052

4. The CCCs and the state: a socio-legal and socio-economic relationship ........ 1054

4.1. The process of institutionalization: a collective decision .................. 1054

4.2. Defining the internal regulations ..................................... 1055

4.3. The creation of a legal entity ............................................ 1055

4.4. Formalizing the social agreement through a contract .................. 1056

4.5. The design: defining the relationship of the CCCS

with the official currency..................................................... 1056

4.6. Perception of relationship with the euro .............................. 1058

4.7. Perception of relationship with central-state Law ....................... 1061

4.8. Relationships between the CCCs and the central state .................. 1063

5. Conclusion: Towards autonomy through CCCs? .............................. 1065

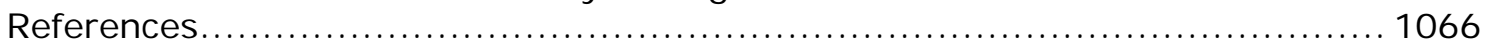

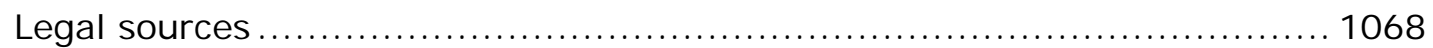

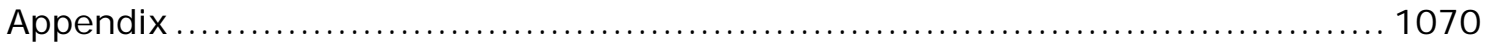




\section{Introduction}

Community and complementary currencies aim to foster systems of exchange mainly based on solidarity, cooperation and mutual trust. They are often designed by social collectives in a complex network of partnerships between territorial organizations, volunteers, civil associations, cooperatives and, recently, local state governments. They are designed to increase self-regulation of the local economy by the community and also to strengthen citizen's engagement with the territorial community as well as to promote democratic forms of social organization.

The currencies are labelled differently according to the social group that creates each one. Some call them "social", others "local", "community", "complementary", or even "alternative". I chose to call them "community and complementary currencies" (from now on, CCCs) but they all consist of systems of exchange parallel to the official currency. Some currencies may assume the form of banknotes or cards, others of virtual or electronic money. The territory can vary according to each currency, but mostly they are regional or strictly local. The currencies differ according to the function, the objectives, the design, the values and principles, and their relationship with the official currency. Some systems are isolated from the official currency, fixing their unit of account through the activity of bartering, time, or virtual mutual credit systems based on credits without interest created in the very moment of transaction, while others are closer to the official currency, like bonds, backed by euros usually at 1:1 exchange rates, and sometimes allowing businesses and users to recover the euros by reconversion. However, even though they all can share technical aspects (such as the form or the design) each CCC has its own normative order and each one relates to the state in a different way.

As a tool, CCCs are designed to promote the self-regulation of the economy by the communities, challenging the supranational-official monetary system by re-directing the economy to the local territory. Also, as a social institution, they represent a body of norms characteristic of the social collectives that have institutionalized the currency, whether they are the associations, the cooperatives or the municipality together with the local shops. In this context, the central research question that guides the present research is: How do the CCCs as monetary schemes and normative orders create spaces of local self-regulation within the state?

In order to approach the complexity of money the question articulates concepts from different disciplines. Answering the question consequently demands two levels of analysis. On the one hand, I will address this question from a socio-economic approach to the CCCs, by contextualizing the cases of the Ekhi and the Txantxi ${ }^{1}$ (in the Spanish Basque Country) and the Eusko (in the French Basque Country), in the current debate and focusing on the relationship between the CCCs and the official currency. On the other hand, I will examine the normative foundations of the CCCs as they are presented by the representatives of the associations (Ekhi and Eusko) and of the local state government (Oñati's municipality) that created and designed the CCCs. By focusing on the perceptions of these social actors that participated in the institutionalization of the CCCs and their internal regulations, I will examine the relationship between the normative order of the CCCs and the normative order of the state. These analyses will enable me to discuss the potential for creating spaces of self-regulation through CCCs.

In section 2 I present a review of the literature and evaluate the current conceptual debate on money and CCCs. I show how the existing literature lacks a substantial account of the normative dimension of the CCCs and the different ways of civil engagement and their relationship with the normative order of the state. Then I introduce the conceptual framework from a combined socio- economic and sociolegal perspective that allows me to develop my central objective, that is to explore the possibilities of local self-regulation through the CCCs within the state. The section

\footnotetext{
${ }^{1}$ The Txantxi was terminated in the summer of 2017 by the municipality of Oñati.
} 
ends by explaining my methodology that corresponds to my research question and to my theoretical framework. Section 3 presents the qualitative data and describes the normative order of the CCCs, suggesting that the more the normative order of the currency get distanced from the central-state institutions the more successful they turn out to be in relation to the capacity of the community to self-regulate the currency. Section 4 addresses the process of institutionalization of the CCCs. First, I develop an analysis of the relationship between the CCCs and the state from a sociolegal perspective. I present the internal documents of the associations and the municipality, that regulate the functioning of the CCCs, trying to show different ways of legal convergence to the state normative order. Then I analyze the relationship between the CCCs and the official currency, from the socio-economic perspective, allowing me to find both common grounds and conflict between the two approaches, enriching the analysis of the CCCs. The section ends by identifying the relationships between the CCCs and the State, considering both approaches. Finally, the conclusion reveals that social actors through the CCCs are able to establish a spatiality, a temporality, different values and purposes, socio-economic functions, forms of governance and social organization, which indicates the potentiality for the CCCs to create institutional space for autonomy of territorial communities or local-state governments.

\section{Methodology and theoretical framework}

\subsection{Literature Review}

The literature on community and complementary currencies (CCCS) reveals the complexity when it comes to definitions of money and a lack of a socio-legal approach to the topic. Even though the terminology used to address this monetary phenomenon is varied ("complementary", "community", "local", "social", "alternative") they share the specificity of being currencies parallel to an official one, that accentuate circulation and exchange rather than accumulation, and are restricted to a territory or community (Primavera 2006, Blanc 2006, Orzi 2012). In relation to the latter, Orzi has argued that this might explain why the monetary authorities tolerate them, but he does not develop this idea further.

In economics, money is a unit of account, a means of exchange or payment and a reserve of value. The Marxist approach also presents money as a commodity (although a unique one). A contemporary movement from different disciplines has proposed a theory of dematerialization that regards money as an agreement, a social contract or a social link. Within this movement, many academics have analyzed the qualitative dimension of money centered on its strong symbolic, cultural and social component (Barber 1977, Bloch 1989, Parry 1989, Zelizer 1989, Lietaer 2001, Primavera 2006, Orzi 2012, Corrons 2015, Blanc 2016). For Zelizer (1989) the impersonality and anonymity of money presented in Marx's theory contribute to the depersonalization of social relations. Moreover, Lietaer (2012) has demonstrated that different forms of money shape different societies and analyzed the prevailing monetary systems as an institutionalization of the arrangements between the government and the financial system. In the same line, Orzi (2012) has observed that the mainstream neoclassical paradigm is based on the assumption of a rational, generic, economic subject, the homo economicus, which justifies the functioning of an independent market, free from all social determinations. His work encourages us to build a qualitative interpretation of currencies starting from the process of socialization, that is, to regard them as social agreements within a network of institutions allowing them to function.

For Blanc (2016), inspired by Polanyi (1957), money is a social institution that takes the form of a system of objects embedded in a system of values. Anthropological approaches to money have also demonstrated the existence of different forms of money in the interplay between western and non-western conceptions (Parry and Bloch 1989). These approaches have emphasized that the symbolism of money is 
related to culturally constructed practices of production, consumption, circulation and exchange, conforming to an abstract system of thought. In this same line, Zelizer (1989) identified the qualitative dimension of money being the social and cultural structures that institutionalize different controls and distinctions in sources, uses, modes of allocation and even the quantity of money. However, Evans (2009) has produced empirical data employing Zelizer's perspective, demonstrating that even though participants claim social value motivations, ongoing participation is more linked to advantageous economic status rather than level of commitment to social values.

Other researchers have emphasized the strong component of economic, ecological and social transformation embedded in the CCCs (Parry and Bloch 1989, Primavera 2001, Borrello and Plasencia 2010, Lietaer et al. 2012, Orzi 2012). Lietaer (2001) stated that social money is capable of generating new forms of economic and social development in a gradual and sustainable process. Orzi (2012) has explored the potential of social currencies oriented towards a social and solidarity economy, based on case studies of CCCs in Argentina. Moreover, Dìdac Sánchez Costa (2012) theorized the CCCs' implicit function of generating social sustainability and sovereignty, based on the experiences of the EcoXarxes in Catalonia, concluding that it reinforces locallyoriented work and empowers socially-excluded groups. He revealed the importance of the CCCs in relation to food sovereignty given that it relocates the economy protecting small units of family agriculture generating stable economic ties based on trust that help to reproduce the social fabric. In this sense, CCCs constitute models of economic, monetary and commercial sovereignty that contends with the conventional monetary system (Sánchez Costa 2012).

Some professionals have analyzed CCCs as a bottom up collective experience that emerged locally but simultaneously can be described as a global phenomenon reacting to periods of crisis (Primavera 2001, Borrello and Plasencia 2010). Seyfang and Longhurst (2015) have presented them as parallel systems of facilitating exchange that result from collective action and as a reaction to the structural failures of the conventional economic and financial systems. Given that they are mostly inspired by critical economics, CCCs challenge conventional economic thought. In this sense this is a bottom-up movement of grassroots innovations promoting alternative perspectives on development, value, economic scale and growth. Borrello and Plasencia (2010) emphasize the nature of social currencies as an expression of resistance to poverty and unemployment, but also as a struggle by ecological and feminist movements for emancipatory purposes. In addition to this, Primavera (2001) considers CCCs to be an ideological mark of resistance to neoliberal globalization, which can create bridges between social movements, as well as new relations with the state.

Blanc and Fare (2013) have analyzed the role of local government in the emergence, development and differentiation of currencies. They built a very precise classification of modes of action of the government but without applying it to a specific case study with original data. They identified two forms of emergence of CCCs: those encouraged at local level by associations and those initiated by local governments or with their support. They recognized that CCCs operate in the grey areas of regulation with the constant risk of illegality. However, they do not describe the legislative framework set up by governments or the normative aspects of the CCCs. Last but not least, from a legal standpoint, Freire (2009) systematized the definition of CCCs on the basis of Brazilian constitutional precepts; identifying and examining legal and regulatory issues, arguing that social currencies should be regarded as public policy instruments for local development compatible with monetary policy. Like any other economic or social activity, any CCC system depends on norms. As no one is obliged to accept any other currency than the official one, or compelled to participate in an alternative currency system, a CCC is, in principle, legal in most countries as a parallel and voluntary system of exchange (Primavera 2001, Freire 2009). Also, Lietaer and Hallsmith (2006) argued that these currencies are considered legally-structured 
instruments that advance the purposes and aims of the users through contract. Similarly, according to the socio-legal theory of MacCormick (2007, p. 34), money is simply a medium of exchange that exists through "the faith humans have in the norms, mostly indeed explicit legal rules of state law, governing the exchange process and the character of legal tender and the right to mint coins or to print and issue bank notes".

The literature lacks a comprehensive socio-legal account of the normative significance of the social organizations and the citizens and their relationship with the state law. This project seeks to add such a dimension to the existing body of literature by studying different approaches to civil engagement embodied in CCCs, and their relationship with the normative order of the state. It also adds to the existing literature by deploying empirical data based on three cases (the Eusko in the French Basque Country and the Ekhi and the Txantxi, in the Spanish Basque Country). Contextualizing the technical and social characteristics of the CCCs in the framework of the current legislation helps to understand the process of designing the functioning of the currency, in such a way that what appears to be technically neutral, is influenced by the existing norms in society and by a collective decision derived from an agreement between the social actors that participate in the institutionalization of the CCCs.

To help bridge this gap, I propose to address the phenomenon of CCCs by combining categories from different disciplinary fields. I chose to employ the socio-economic categories developed by Jérôme Blanc to contextualize the CCCs within the existing literature and then to apply a socio-legal approach to the field based on MacCormick to stress the normative foundations and the variations of the CCCs in a way that socioeconomics do not, considering the perspective of the social actors that participated in the process of institutionalization of the CCCs. By integrating insights and producing an interdisciplinary understanding of the CCCs I aim to contribute to discover common ground between insights and also to identify conflicts among them.

\subsection{A socio-economic approach to CCCs}

Blanc and Fare (2013) distinguish four generations of CCCs:

1. First-generation schemes: non-convertible currencies, with few economic partnerships and remote from governments and public administrations;

2. Second-generation schemes: non-convertible time-based currencies and frequent partnerships for social practices;

3. Third-generation schemes: convertible currencies and the search for advanced partnerships with local economic objectives;

4. Fourth-generation schemes: convertible currencies that are part of multiple projects with a central role for local governments. For the present study, I will focus on the third and the fourth-generation schemes, because the cases of the Eusko, the Ekhi and the Txantxi are monetary schemes based on convertible currencies.

The third-generation schemes are CCCs inspired by the Brazilian Palmas, founded in 1998 and issued by a community bank in Brazil that works under the principle of solidarity and social economy, and on the German Chiemgauer, launched in 2003 in southern Bavaria. According to Blanc and Fare, this generation of monetary schemes is the result of community initiatives, possibly adopting cooperative or associative forms. Some involve partnerships with local ethical co-operative banking institutions or territorial organizations. So, the expansion of the project is not necessarily related to the support of governments, even if they participate. Most CCCs of this generation are backed by an equivalent reserve held in the national currency. It is possible to join the scheme by converting national currency into CCCs. Converting CCCs back into national currency is also possible but is discouraged by exit penalties. The CCCs can also be used in conjunction with the national currency. They try to generate an economic impact at the local level through the inclusion of territorial producers, aiming at daily consumer behavior and relying on local businesses and stores to accept the local currency. 
The fourth-generation schemes are CCCs developed also in early 2000s, but involved multiple projects and a central role for local governments. This model is the least developed so far. It often integrates environmental concerns and a multiplicity of projects that imply technical costs. They involve complex partnerships bringing together local governments, economic actors, and national or even European organizations or programs.

As Blanc (2016) states, the challenges for community experimentation and initiatives is their institutionalization and the recognition of their social utility. His socioeconomic theory addresses the issue of "plurality of monies". His qualitative interpretation of money refers to four basic binary relations between currencies: commensurability, convertibility, co-use and coincidence of spheres of use. Through their combinations, four means of linking monies are identified: substitutability, simultaneity, supplementarity and autonomy. This framework allows us to understand competition and complementarity between a plurality of monies in a dynamic and interactive way. He defines them as follow:

1. Commensurability: the qualitative dimensions of money (the symbolic universe, the monetary form it takes, the earmarking and the authenticity) determine the ability of comparison with other currencies. So, the level of commensurability defines the possibility of obtaining a common valuation through a fixed exchange rate.

2. Convertibility: conversion means the transformation of one monetary asset into another. It is the quantitative dimension of comparison between two or more monetary assets. Conversion therefore requires commensurability.

3. Co-use: when various means of payment can be used simultaneously. This is linked to commensurability and convertibility.

4. Coincidence of spheres of uses: various monetary assets can be used in the same socio- economic sphere (for the same set of goods, services, participants and within the same territory).

Through the combination of these four-binary relations, Blanc analyzes the interactions between monies in terms of different levels of competition and complementarity. He defines these possible interactions as follows:

1. Substitutability: results from the binary relation of commensurability and convertibility. Competition is more intense as convertibility becomes easier, spheres of use coincide, monies can be used simultaneously and the qualitative dimensions are (highly) comparable. The monies are fully fungible. The symbolic universe then determines possible substitutions between local and national currencies.

2. Simultaneity: results from the combination of co-use and coincidence of spheres of use.

3. Supplementarity: refers to a partial coincidence of the spheres of use of different monies. This coincidence may occur in two scenarios: qualitative supplementarity that is very rare in industrial societies when the currencies are not convertible but still commensurable, leading to no co-use, but linking the spheres of use qualitatively in terms of the overlap in symbolic universe; and quantitative supplementarity when the monies are commensurable and also convertible, creating co-use and a quantitative link between the spheres of use fixed by the quantitative exchange of the monies. Competition is higher as co-use and coincidence of spheres of uses are converging. So, supplementarity is a form of complementarity that enables competition when it is quantitative.

4. Autonomy: when separate units of account exist with no parity or fixity between them. There are separate symbolic universes ${ }^{2}$ and consequently low or no commensurability and convertibility. Blanc refers to autonomy as the ability to create one's own law. The level of (in)commensurability and (in)convertibility generates strong or low autonomy. Autonomy impedes competition when convertibility and commensurability are restrained. Therefore, there is higher autonomy when symbolic universes are incompatible and spheres of use are clearly separated.

The conceptual framework for CCCs provided by Blanc stresses the key role of symbolic universes in differentiating and especially "measuring" or generalizing the normative

\footnotetext{
2 The symbolic universe is related to the social representations, characterized by a hierarchy of values and moral norms (Blanc 2016).
} 
potential of using CCCs against the state. By expanding the role of what is "commensurable" for Blanc, the qualitative dimension, I open for a closer scrutiny the factors enable autonomy, in the sense of creating one's own law, and how autonomy may be built within the state.

\subsection{A socio-legal approach to CCCs}

From the socio-legal perspective of MacCormick (2007), an institution is a type of legal mechanism that serves as a scheme of coordination of mutual expectations. "Norm-users" (individuals) orient their behavior in conformity to a set of norms of that institution, creating a sense of order and thereby security in anonymous and impersonal relations. Eventually, this legal mechanism reinforces interdependency, mutual trust and autonomy (Bengoetxea 2015).

In the institutional theory of Neil MacCormick norms and institutions are intrinsically connected. It is a dialectical relation, since the institutions promote (through the institutionalization of values and social practices) a normative order that is expected to be practiced and respected among the members (norm-users) of that given system. This corresponds to the notion of a system of mutual expectations, which ultimately contributes to reinforcing autonomy within that system. Moreover, social change can be achieved through institutions. In this sense, institutions can promote new (or not new) norms of behavior within a social network. However, there is a conceptual priority in the socio-legal theory of Neil MacCormick, of the "use of the norm" prior to its creation by an authority.

Under this approach, a normative order (and use of the norms) precedes its institutionalization. Norms already exist in society prior to institutions, through the thought, behavior and social practices of individuals. From this angle, individuals are "norm-users" that interact by conducting their behavior in relation to a system of mutual expectations, that is, of what one ought to do in a certain setting (under the codes of that normative order). So, norm-users act in relation to existing norms (what is already instituted in society). Also, they can create their own norms - their own social practices, values, use of language, morality, which vary with time and whereby norms change as well-. They can also institutionalize these norms. When a normative order is institutionalized, the institution complies with new norms belonging to that order, created by the social actors, and also interacts, in different degrees and intensities, with state law and with supra-state law, as represented by various legal institutions of the European Union. This claim rejects the view that law is primarily associated with the state, and suggests the possibility of thinking of a law that comes from above in the form of supra-state institutions (such as the European Union), of central-state institutions, of local-state institutions (municipalities) and, also, from below in various forms of local institutions, that are themselves institutional normative orders, and thus more or less autonomous sources of law (Ewald 1997). Such a picture would contribute to understanding the interactions between different forms of laws within the state, and different ways to achieve autonomy.

For Neil MacCormick, law is an "institutional normative order" that aspires to create a social order, not in the sense of command but of orderliness. From this perspective, state law is an institutionalized normative order among many. Neil MacCormick allows thinking of social reality as a plurality of normative orders. What all these normative orders have in common is the aspiration of order, a conception of justice and a pretension of legitimacy and validity within that normative order.

This dynamic point of view that MacCormick adds to legal theory allows me to regard the institutions of the CCCs as something not static, but rather in movement. On the one hand, it depends on the ability to adapt the institutionalized normative order of CCCs to the variations in the norms of the territorial community. On the other hand, 
their viability also depends on the articulations of the normative order of the CCCS with the normative order of the state. ${ }^{3}$

The institutional socio-legal theory of Neil MacCormick helps me to expand the socioeconomic analysis in the sense that it allows me to examine the possibility for social groups to develop norms from below, and then to institutionalize them, interacting with the state normative order. In this sense, the "norm-users" then become "normcreators" within new normative orders that they themselves define. Such normcreators would be the designers in relation to CCCs. Therefore, this combination allows me to observe the interaction between different normative orders embedded in the CCCs and how they make or take space from each other, eventually creating autonomy in the communities they inhabit. Hence, I combine the socio-economic analysis of the qualitative dimensions of the CCCs with an analysis of the normative order embedded in the currencies. This requires qualitative data about the representatives of the associations and the municipality designing the CCCs, since they are the key to understand the normative order that they created, and that defines the CCCs in relation to the central-state-law and the supra-state-law.

In relation to the EU and different levels of state order, for the purposes of this work the key relationship is between the institution of CCCs and the central-state, which today is also guided by the EU. However, this is only relevant when EU-norms reach the social tissue of the normative orders established in society (such as the euro and some other regulations). The central state appropriates these EU norms (and the euro) and makes itself responsible for the maintenance of them, therefore the central state is still the main institution. This is also reflected in the different attitudes of the French and Spanish states. Therefore, the study is limited to the relationship between the central state and the CCCs to see if the social actors create autonomy within the state through the CCCs.

\subsection{Methodology}

The present article shows the findings of an exploratory research into three cases of CCCs in the Basque Country, the Eusko, the Ekhi and the Txantxi, carried out during the year 2017. The aim is to explore the possibilities of local self-regulation through CCCs within the state. To conduct the field research a qualitative methodology for the analysis of primary data was selected. The use of qualitative methods was suitable to meet the research's aims since small amounts of data can reveal the meanings, perceptions and understandings about social practices in the construction of the CCCs. For this reason, face-to-face semi-structured interviews combined with participant observation have proven to be an appropriate method of research, in the sense that they allowed to interpret experiences by viewing the world through the eyes of the individuals being studied (Travers 2013). In accordance with the research question and in the frame of the qualitative methodology, a non-probability sampling method was selected. The population under study is the representatives of the associations of the CCCs and the Municipality of Oñati. The type of qualitative sampling was snowball (Tranter 2013). Six face-to-face semi-structured interviews were conducted. In order to get an in-depth understanding of the social setting, participant observation was carried out in the cities and towns where the CCCs work, exchanging euros for CCCs and consuming in local shops with local currency. The data is, however, limited to the viewpoint of the designers of the CCCs, the representatives of the associations and the municipalities who promoted the institutionalization of the CCCs. Finally, the results of the fieldwork were then analyzed in relation to the current legislations of France and Spain. The method of documentary analysis for the secondary data, was employed for the systematization of state regulations and internal statuses and rules of functioning of CCCs.

\footnotetext{
3 The state is understood in terms of Oszlak (1981), as an institutional apparatus and also as a mechanism for the articulation of social relations.
} 


\section{Normative order of the CCCs}

\subsection{Emergence and characteristics of the organizations and political parties}

The Eusko corresponds to what Blanc defined as "third-generation of monetary schemes". It is the result of a community initiative, taking the status of an association. The idea of the Eusko emerged in June 2011 among volunteers and activists that created the Association AMBES (Association for the Creation of the Local, Ecological and Basque Currency), to start the project learning from other experiences in Europe, like Villeneuve-sur-Lot, Sol Violette in Toulouse and Chiemgauer in Bavaria. Later they created the association Euskal Moneta-Monnaie Local du Pays Basque, to manage the Eusko, launched in early 2012. The name of the currency was decided collectively and in a democratic way: 380 names were proposed by volunteers and then 2000 volunteers voted and chose Eusko, which means Basque.

The activists concerned are left-wing supporters of ecological movements and defenders of the Basque language (euskera). Many of them had participated in the counter-summit on climate change, in Cancun December 2010, following the slogan "To Change the System Not the Climate". Bizi, an independent anti-globalization association that rejects all forms of violent action or clandestine strategy, participated in this process. The currency was designed for the city of Bayonne, in the French Basque Country [known there as the Pays Basque nord (I parralde), while the part of the Basque Country located in Spain is called Hegoalde, which means South part of Basque Country]:

In Eusko we have members that are separatist, ecologists, a bit of everything (...). The challenge is to link people. (Co-presidents of Euskal Moneta)

As regards the Ekhi, it also belongs to this third generation of monetary schemes. The project came right after the Eusko. The project was born with the movement Desazkundea, an anti-growth movement that follow the line of Good Living (Buen Vivir), and is supported by activists critical of unlimited growth of the economy:

It is not possible to infinitely grow in the economy, within a world that is finite. (Representative of Ekhi)

The political group Desazkundea emerged after the movement of 15-M (also known as the movement of the indignant) that took place in 2011 in Spain, claiming for real democracy and with the slogan "We Are Not Commodities of the Politicians and the Bankers". Since then, they have been promoting projects that link anti-growth with feminism, like community gardens, social currency and promoting horizontal relations inside organizations. Their field of political action is Bizkaia. The idea of the Ekhi started in October 2011 and was put into circulation in 2013. It was designed to start working in Bilbao-Old Town but with the aim of expanding the initiative to all Bizkaia (a province of the Spanish Basque Country). Ekhi means sun, the name was chosen collectively by the people engaged with the social movement in assembly.

The Txantxi is a "fourth-generation" monetary scheme. The role of the local government was central in the creation of this project and to insert it into a complex multiplicity of projects linked to environmental issues. This currency came right after the Ekhi in Bilbao. It was devised by the municipality of Oñati, located in Gipuzkoa (Spanish Basque Country), during the term of office as mayor of Mikel Biain from the political party Euskal Herria Bildu (EH Bildu). The currency was part of a complex project of different alternatives that included the creation of public vegetable gardens, communal compost and recycling. The recycling project and the communal compost were launched in 2013. They had invited technicians from the Environmental Services Cooperative of Artelatz (Cooperativa de Servicios Medioambientales Artelatz), to offer workshops and informative talks to the citizens of Oñati about composting. Later, in 2015 , they launched a project of public vegetable gardens to learn in a space of agroecology. At the beginning, the help of the municipality was needed to cover the expenses of water, energy and the infrastructure, and by now, it is a self-administered 
model within a policy of community development. In this context, the Txantxi was put into circulation at the end of 2014. The currency was called Txantxi in reference to the nickname given to the people living in Oñati, txantxiku, which means frog.

In the case of Ekhi and Eusko, they were the result of a bottom-up movement, whereas the Txantxi was more a top-down project, launched by the local state government in collaboration with local businesses. However, they share the characteristic of being the result of collective action and a search for consensus among different local actors in a given territory to design a tool (currency) for the local community. In the three cases the interviewees highlight that the process of emergence was democratic and inclusive of civil society.

\subsection{Perception of the CCC's}

The representatives of the CCC's perceive their currency in slightly different ways. The Eusko is a "complementary currency" that serves as

a tool of the territory/community for the people to create real economy. That is complementary to the official currency and also to the projects of the territory. Our objective is to link the dynamics that already exist, because the currency is a very transversal tool with the capacity of gathering. We will make the things that the others don't and we are doing it together. It is a model of cooperation that can be replicated in other parts of the world. And it is a tool of self-governing, to build the country that we want, to generate and give a positive vision of general interest. (Copresident of Euskal Moneta)

The representative of the Ekhi defined the currency as "social money":

a way of making use of money in a more conscious way, capable of changing the society with the daily act of purchasing. Every time that I use money I vote. By using Ekhi I am voting in a different way than the Euro, because the Ekhi implies a local and sustainable economy, with values within a network that integrate the Ekhi. It is a currency for a transition and the objective is to change something real, small and viable, and replicable. (Representative of Ekhi)

As for the designer of the Txantxi "local currency":

is a tool of the territory to compete at a global level and has to give answers to the different dimensions that form the community: the cultural, the participative, the socio-economic, the institutional, the energetic, the social capital, the territorial, etc. The Txantxi emerged from the socio-economic sphere. Once we have that tool, we have to think possible functions that the Txantxi can have for each of those dimensions (...). The actual local government, the businesses and consumers are responsible for the functioning of the currency but it has to be accompanied by a public support and participation. (Designer of Txantxi)

In the three cases the interviewees identify the CCCs as a local tool that is complementary to the official currency (the euro). Also, they regard the currency as a tool of democratization of economic, social and political power, respectful of the state and aligned with the needs of the territory and community.

\subsection{Perception of the relationship between the CCC's and the Community}

In the three cases the interviewees identified the dialectical relation between the community and the CCCs:

The Eusko is a project of General Interest (...). In the Eusko there is a spirit of commitment, a terrain that is favorable because people get implicated in collective movements. The identity of the project is connected to that of the territory. The community and the territory are very important. Because we believe that the community supports the currency, but the currency also makes the community. (Copresidents of Euskal Moneta)

Through the community currency is possible to break the individual dynamic of the capitalism, of 'I only act out of self-interest'. Ekhi creates community, a common link and a sense of belonging (...) because the Ekhi implies an economy with values, 
therefore that money is obliged to circulate in that network of values that integrate the Ekhi. (Representative of Ekhi)

The Town Hall was the facilitator of the means to create and support the Txantxi but we encourage businesses to be the leaders. (Oñati's Mayor)

Moreover,

Txantxi is the tool. The community is the one assigning the function and the ideological mark. We did a work of socialization but at the end there was lack of public commitment. (Designer of Txantxi)

In the three cases local commitment in the organization and management of the CCC is a relevant factor that appears to affect the functioning of the currency. According to the perception of the interviewees, the more the social practice (use of CCCs) is guided by the values and customs of the community, the better it works. But this implies that the social movements and the municipality need to have certain success in opening the dialogue to more sectors in society. On the other hand, if users stop adjusting their behavior to the normative order of the CCCs, apparently, its functioning declines.

\subsection{Objectives and values}

The Eusko aims at

relocating the economy and the promotion of the public use of the euskera (...), the challenge is to link people, to compel people (...), to generate a network with sense for people. (Co-presidents of Euskal Moneta)

To promote this, they generated projects to accompany solidarity and ecological practices, by means of cooperation between participants of the currency and other territorial organizations. All these initiatives are decided in a democratic way (all participants can vote) through an assembly that decides on the functions of the currency.

The objectives of Ekhi are

to recover money as a means of exchange and to generate an economy with values (...). What we created through the currency is not only that people engaged and support the local economy, but to generate a network with values between the people and the businesses. Now people consume in the local shop of the neighbor (...). That's why our objective is the transition. (Representative of Ekhi)

Governing the currency through assemblies and by means of association with other organisations allowed to build support for the social network of the Ekhi.

The Txantxi's objectives are

to limit the shift towards spending outside Oñati, to support and stimulate demand in localshops and to make visible the citizen and entrepreneurial commitment for the local. (Designer of Txantxi)

For this purpose, the municipality enabled a technical board (mostly made up from local businesses and representatives of the municipality) to invite citizens to participate in the governing of the Txantxi.

In all three cases the CCCs attempt to bring about social, cultural, economic and political changes, which are part of a learning process that is slow and local, but with ambitious aims. For this they develop strategies of self-governance by the community, through assemblies or boards. In the case of the Txantxi, this is less visible because of the strong presence of the local-state government, under the governing political party. This appears to have been a factor affecting the level of engagement of the community with the project of the currency. Anyway, those who wanted to participate in the design and organization of the Txantxi could join the Technical Board. Instead the Eusko, and to a lesser degree the Ekhi, have the particularity of being projects that are constantly trying to include new sectors, from 
different political backgrounds and interests, meeting in assemblies regulated by internal statuses to guarantee the equal participation among partners (members of the associations). In this sense, their normative orders clearly emerged from below. The Txantxi, even though it is a more top-down project conducted by the local-state government, is also from below in relation to the central-state normative order. Moreover, apparently, the more the projects of the currency become distanced from the State institutions the more successful they turn out to be in relation to the capacity of the community to self- regulate the currency.

From the interviews and the internal statutes, the following variables describing the normative order of the CCCs were revealed:

TABLE 1

\begin{tabular}{|c|c|c|c|}
\hline $\begin{array}{c}\begin{array}{c}\text { Dimensions of the } \\
\text { normative order } \\
\text { of the CCCs }\end{array} \\
\end{array}$ & Eusko & Ekhi Txanpona & Txantxi \\
\hline Designers & $\begin{array}{l}\text { Volunteers and activists } \\
\text { that created the } \\
\text { Association AMBES (for } \\
\text { the Ecological, Solidarity } \\
\text { and Basque Currency) }\end{array}$ & $\begin{array}{l}\text { Volunteers and } \\
\text { activists of } \\
\text { Desazkundea }\end{array}$ & $\begin{array}{l}\text { Oñati’s Town } \\
\text { Hall by the } \\
\text { Political Party } \\
\text { Euskal Herria } \\
\text { Bildu }\end{array}$ \\
\hline $\begin{array}{l}\text { Type of } \\
\text { organization }\end{array}$ & $\begin{array}{l}\text { Association } \\
\text { (Association Euskal } \\
\text { Moneta) }\end{array}$ & $\begin{array}{l}\text { Association (Ekhi } \\
\text { Elkartea) in } \\
\text { partnership with } \\
\text { cooperative (Goiener) }\end{array}$ & Municipality \\
\hline Temporality & Mid-2011- unlimited & End-2011- unlimited & $\begin{array}{l}\text { End 2013-ended in } \\
\text { July } 2017\end{array}$ \\
\hline Aims & $\begin{array}{l}\text { To affect the nature of the } \\
\text { local economy }\end{array}$ & $\begin{array}{l}\text { To affect } \\
\text { exchange relations }\end{array}$ & $\begin{array}{l}\text { To protect } \\
\text { the local economy }\end{array}$ \\
\hline Guiding principle & $\begin{array}{l}\text { Solidarity: to cooperate with } \\
\text { what is in the territory }\end{array}$ & $\begin{array}{l}\text { Redistribution: to relocate } \\
\text { wealth in society }\end{array}$ & $\begin{array}{l}\text { Resilience: to } \\
\text { strengthen the local } \\
\text { economy }\end{array}$ \\
\hline Ethical values & $\begin{array}{l}\text { Mutual respect, equity, } \\
\text { non-profit orientation }\end{array}$ & $\begin{array}{l}\text { Social responsibility, } \\
\text { mutual trust, gender } \\
\text { equality, non-profit } \\
\text { orientation, social justice }\end{array}$ & $\begin{array}{l}\text { Mutual help, social } \\
\text { participation }\end{array}$ \\
\hline Spatiality & $\begin{array}{l}\text { Bayonne (French } \\
\text { Basque Country) }\end{array}$ & $\begin{array}{l}\text { Bilbao Old Town } \\
\text { (Spanish Basque } \\
\text { Country) }\end{array}$ & $\begin{array}{l}\text { Oñati (Spanish } \\
\text { Basque Country) }\end{array}$ \\
\hline $\begin{array}{l}\text { Decision-making } \\
\text { forum }\end{array}$ & $\begin{array}{l}\text { General assembly and } \\
\text { Committees }\end{array}$ & General assembly & Technical Board \\
\hline $\begin{array}{l}\text { Perception of } \\
\text { justice }\end{array}$ & $\begin{array}{l}\text { Equity, recovering the } \\
\text { community and the Basque } \\
\text { language }\end{array}$ & $\begin{array}{l}\text { Social justice, achieving } \\
\text { the dignity of labor, } \\
\text { gender equality, and use } \\
\text { of the Basque language }\end{array}$ & $\begin{array}{l}\text { Liberty of election, } \\
\text { through keeping the } \\
\text { local economy and } \\
\text { the community alive }\end{array}$ \\
\hline $\begin{array}{l}\text { Perception of } \\
\text { CCCs }\end{array}$ & $\begin{array}{l}\text { Complementary currency: a } \\
\text { tool for the community to } \\
\text { create real economy }\end{array}$ & $\begin{array}{l}\text { Social money: a way of } \\
\text { making use of money, } \\
\text { capable of changing the } \\
\text { habits in society }\end{array}$ & $\begin{array}{l}\text { Local currency: a } \\
\text { tool of the territory } \\
\text { to compete at a } \\
\text { global level }\end{array}$ \\
\hline Participants & $\begin{array}{l}\text { Through membership: the } \\
\text { active members, the users } \\
\text { and the suppliers } \\
\text { (businesses, shops and } \\
\text { independent professionals). } \\
\text { Non-adhered members: } \\
\text { territorial collectives }\end{array}$ & $\begin{array}{l}\text { Through membership: The } \\
\text { users and the local } \\
\text { businesses } \\
\text { Non-adhered members: } \\
\text { activists and volunteers } \\
\text { from other territorial } \\
\text { organization }\end{array}$ & $\begin{array}{l}\text { Businesses/suppliers } \\
\text { from Oñati that sign } \\
\text { a contract with the } \\
\text { Town Hall, and } \\
\text { users, who } \\
\text { voluntarily } \\
\text { exchange euros for } \\
\text { Txantxis. }\end{array}$ \\
\hline
\end{tabular}

Table 1. Dimensions of the normative order of the CCCs in

the Basque Country.

Source: Own preparation based on research data. 
Table 1 shows that the social collectives and the local state government opted to create a distinct normative order from the central state normative order. Through the CCCs they institutionalized a social practice (the use of money), values and principles, a form of social organization, a temporal and geographical spatiality, customs and ways of administrating the social norms through collective decision-making. Moreover, what I observed in the process of emergence of the CCCs (as a social institution) is that the components that make up the institution were firstly agreed and then institutionalized by social actors that already shared (in different degrees) some interests, values, practices, a use of language, a morality (that conforms to the normative order of a given territorial community). The normative order institutionalized in the CCCs represents the cosmovision of the social actors that participate in the process of decision-making. Therefore, the three cases share the challenge to have some success in articulating the normative order embedded in the institution of CCCs with that of the territory. They try to achieve this through a form of political and social organization that is horizontal and associative. In this sense, in the three cases norms come first and later are institutionalized by the social actors (the social movements and municipality together with the designers and promoters of the CCCs).

Common to the three CCCs is that they promote change in the local community by making use of the currencies and activating the values inhabiting them. These correspond to the ethical values and the aims that each currency promotes: the Eusko, non-profit orientation, mutual respect and equity for a change in the nature of the local economy; the Ekhi, non-profit orientation, mutual trust and social justice for a change in the exchange relation, the Txantxi mutual help for promoting the local economy. Therefore, in a dialectical way, at the same time that norms precede institutionalization, the institution of the CCCs is oriented to generating a change in the social practice of exchange, by setting up common norms that serve as a scheme of coordination of mutual expectations.

This normative order is formalized through legal institutionalization of the CCCs, creating a legal entity (the association, the cooperative) and articulating with the municipality, with statutes and norms that comply in different ways with the centralstate normative order. The following section will further analyze this process of institutionalization within the state order.

\section{The CCCs and the state: a socio-legal and socio-economic relationship}

\subsection{The process of institutionalization: a collective decision}

The internal regulations in the three cases, were created by the organizations/municipality together with the participants who agreed on formalizing the institutionalization of the normative order of the CCC's:

In the Eusko,

the social collective created a pre-project, and for one year we have been organizing open meetings for discussions on the name, the rules of functioning and administration until we created the project and statutes. (Co-presidents of Euskal Moneta)

In the Ekhi,

[d] uring the years 2011-2013 the social collective organized a board with 150 participants from different territorial organizations, to vote on the name of the currency and we defined the values of the project. (Representative of Ekhi)

In the Txantxi,

the Town Hall was the facilitator and the promotor of the currency. In 2013, we invited people from Ekhi and we organized an assembly with the local shops to vote the rules of functioning and the characteristics of the model that we wanted for Oñati. (Designer of Txantxi) 


\subsection{Defining the internal regulations}

The result of these meetings and debates was the formalization of the normative order of the CCC's into a set of internal regulatory documents that comply in different ways with the French/Spanish state law. The normative order of the Eusko is formalized in two legal documents that were published in 2013, when the project was launched to the public (31/01/2013): the Rules of Functioning and the Statutes of the association Euskal Moneta-Monnaie locale du Pays Basque (26 January 2013). Recently, they have published a third document on General Conditions for the Use of Electronic Eusko (March 2017), addressing the new electronic card (Euskokart), launched on the $19^{\text {th }}$ of March 2017. This document comprises the same Statutes and the Conditions of use, the contract between the association Euskal Moneta and each individual relative to the payments in Eusko, and adds a re-definition of Eusko as "electronic money" as follows: "The Eusko is a local and complementary currency that is electronic according to the articles L.311-5 and L.311-6 of the French Financial Code, circulating in the territory of the Basque Country" (Euskal Moneta 2017).

As for the Txantxi three documents crystalize the normative order. These are the Regulatory statute of the Project Elkharri Lagunduz, the Document of Adhesion to the project Elkarri Lagunduz and the Project Elkarri Lagunduz: Industry as an Opportunity. The project Elkharri Lagunduz (mutual help in Basque) is regulated by the Normative of Oñati (28 of November, 2014, updated in 2016). It was issued by the Town Hall under the article 49 of the Law 7/1985, 2 of April, 1985, Regulation on the Foundations of Local Governance, and it was examined by the Dependencias Municipales of the historic territory of Gipuzkoa (Basque Country, Spain).

Finally, the Ekhi formalized its normative order in two documents: the Baloreen Koadernoak and the Project Ekhi, which contemplates the rules of functioning and administrations of the currency. By means of this document, the Ekhi acquires its functions and meaning, shared among the anonymous participants. The document defines the Ekhi as a local currency based on the official currency, the Euro, and is oriented to democratize money in the community.

\subsection{The creation of a legal entity}

In the cases of the Eusko and the Ekhi, they created a legal entity with juridical personality in the form of an association. In contrast, the Txantxi is backed by the legal identity of the Town Hall (local state government). These entities are created and structured following the legal provisions of the French and the Spanish state.

The Eusko is issued and administered by the association Euskal Moneta-Monnaie locale du Pays Basque. Inside the association they have a Pilot Committee in charge of supervising the functioning. For the Euskokart, they created the Compte Dédié that is a Credit Cooperative, to store all the euros and to guarantee that at all times the equivalent amount of Euskos in circulation in euros are deposited in this cooperative.

Since May 2013, Ekhi Txanpona is inscribed as an independent association in the official register in the Basque Government. The association issues the Ekhis and is in charge of supervising its functioning. As for the electronic Ekhi, the association signed a collaboration agreement ( 14 J une 2015) with Goiener (a cooperative of generation and consumption of renewable energy), to expand the project and to administer the electronic Ekhi. This agreement establishes the common ground of values that links the entities. As for the actual legal situation of the Ekhi, they are waiting for the authorization from the Spanish Central Bank to enable Cooperative Goiener to issue the electronic Ekhi. The Ekhi in the form of paper money does not work any longer. The cooperative Goiener is the legal entity that complies with the regulations and the normative order of the state. It has its own legal documents as well. These are the Social Statutes of Goiener S.Coop, the General Conditions of the Contract of Energy Supply, and the Internal Regulatory Regime (J anuary 2017). These documents meet 
the objectives and values of the Ekhi, such as the promotion of social and solidary economy, the participation and the dignity of labor, and the decisions taken horizontally through elections.

As for the Txantxi, it is the local state government at the level of the municipalities (the Town Hall), that is administering, supervising and issuing the Txantxi. So, they did not have to create an association for the institutionalization of the currency.

\subsection{Formalizing the social agreement through a contract}

To join the system of the CCCs, in the Eusko and the Ekhi is possible to do it by paying a membership subscription to the association and agree with the terms of the internal documents that regulate the functioning and ruling of the CCCs. In the Txantxi, users can join the scheme by converting euros into Txantxis in the exchange office that is in the Town Hall, while stores can join the system by signing a contract that is renewed every year with the Town Hall. In all three cases the agreements are voluntary and formalized through a contract, by virtue of which participants agree to exchange goods and services with the CCCs and to obey the normative of the CCCs. The use of a contract is a legal strategy validated by the state law. It serves as a general scheme to guide the conducts and to control that the commitments of the parties involved are met, but also to validate and legitimize the normative order of the CCCs from the point of view of the state normative order. It is part of the legal strategies employed by social actors to formalize the normative order of the CCCs.

\subsection{The design: defining the relationship of the CCCs with the official currency}

In order to have the project of the CCCs legally set up, the design of the currency is adapted to the normative order of the State. The Spanish and French states incorporate in their normative order the norms of the European Union, including those of the Euro, for states which have joined it as these two states have. According to the European Commission, official currencies are those currencies that are administered by a state or, like the euro, by a supranational structure. Within the euro-zone, the euro is the only money that has the status of legal tender (article 128 of the Treaty on the Functioning of the European Union, of 2008, and article 11 of Council Regulation EC/974/98, of 1998). Legal tender means that "in the absence of an agreement of the means of payment, the creditor is obliged to accept a payment made in euro which subsequently discharges the debtor from his payment obligation" (European Commission n.d.). However, the EU Commission states that during transactions, contractual parties are free to use "privately issued money like local exchange trading systems (e.g. voucher-based payments systems in certain communities) or virtual currency schemes (e.g. Bitcoin) (...) in that way these forms of private money can be considered as economic assets". They are subject to tax law, business law, and anti-money laundering law; but, as they are not official currency, they are not governed by monetary law.

As for electronic money, the Spanish and French state incorporated the EU Directive 2009/110 (16 September 2009), on the taking up, pursuit and prudential supervision of the business of electronic money institutions and the EU Directive 2007/64 (13 November 2007) on payment services in the internal market. These two directives establish a legal framework for prudential requirements for a new category of payment services providers and institutions to make sure that issuing entities are financially stable. The objectives are to remove barriers to market entry and facilitate "the taking up and pursuit of the business of electronic money issuance, the rules to which electronic money institutions are subject need to be reviewed so as to ensure a level playing field for all payment services providers" (Directive 2009/110/EC, 16 September 2009). This directive does not apply to instruments designed to address precise needs that can be used only in a limited way, in a network of services in a specific store or chains of store, under direct commercial agreement, to acquire a limited range of goods or services (e.g. petrol cards, membership cards, public 
transport cards, vouchers). The exemption of Directive 2009/110/EC (16 September 2009) would not apply to instruments that are of general-purpose. According to this directive, an "electronic money institution" is a legal person that has been authorized to issue electronic money, and "electronic money" is electronically or magnetically stored monetary value, which is issued on receipt of funds for making payment transactions and which is accepted by another natural or legal person. The directive demands a regime for initial capital to protect the consumer. Electronic money institutions are also subjected to effective anti-money laundering and anti-terrorist financing rules. Electronic money institutions are not allowed to grant credit from the funds received or to grant interest.

In Spain, the directive was incorporated under the state law 21/2011 (26 July 2011) on Electronic Money and has been reinforced with two decrees: Decree 712/2010 (28 May 2010) on the legal regime for payment services and entities of payment and later the Decree 778/ 2012 (4 May 2012) on entities of electronic money. Contrasting with Spain, the French state opened a space for the development of local currencies that accompany a project of solidarity economy. Since the year 2014, the Eusko is considered a "local complementary currency" by the state normative order, according to the law 856/2014 (2014-856, of 31 July 2014) on Social and Solidarity Economy. This law defines the social and solidarity economy as a mode of developing the economy adapted to all domains of human activity following certain conditions like democratic governance, organized and defined by the statutes authorized by a general assembly, with complete information of the participation, the members, the financial contributions, and oriented to other purposes than profit; promoting the cooperative activity. Article 16 of the law mentions "local and complementary currencies", allowing the entities of social and solidary economy, like the cooperatives and the associations, to issue and administrate CCCs. The local complementary currencies constitute a title of payment recognized by the Monetary and Financial Code of the French State, used among the adherent members of the association. Eusko adapts its definition to this law, as we can observe in its legal documents where the Eusko is defined as a complementary and local currency generated democratically by the non-profit association Euskal Moneta, registered in the Town Hall of Bayonne. Moreover, the French state under the law 1321/2016 (7 October 2016) introduced the idea of "economy of the gift" (de la donnée), authorizing the issuers of local and complementary currencies to introduce the tools of digital payment without prior authorization up to a limit of 1 million euros of transaction is reached in the course of 12 rolling months.

The design and functioning of the CCCs were adapted to these regulations. At the beginning, the Eusko started working with coupon-paper money, and since March 2017 they launched an electronic card (the EuskoKart). The Eusko adapted the design and functioning of the new electronic card to the legal provisions of the state. Now, the euros received by Euskal Moneta in the moment of exchange for Euskos, are deposited in an account of a Credit Cooperative and in an account of the Caisse solidaire devoted to solidarity projects in the community.

The association Euskal Moneta obtained an exemption under the regulations governing payment service providers from the Autorité de Contrôle Prudential et de Resolution (ACPR; dependent on the French Central Bank and responsible for ensuring compliance with the Monetary and Financial Code). Currently, four municipalities adhered to the Eusko project through an agreement. In chronological order they are: Hendaye, Ustaritz, Mendionde and Bayonne. Therefore, the Eusko managed to gain an institutional space within the state normative order to expand its project. Also, the French state position towards the CCCs is different, in the sense that it recognizes and allows them to be self-administered within a limited territory and in a limited network of users, and under the conditions of promoting solidarity economy. The Ekhi is trying to do the same in Spain. They designed an online application (virtualintangible) to make transactions through any electronic device. It is not launched yet as they are waiting for the legal authorization of the Spanish central bank (as the 
Eusko did in France) to have exemption under the EU directive on electronic money institutions. However, the legislation of the Spanish state is very protective of the supranational currency, which makes the authorization process difficult. The Txantxi always consisted of coupon-paper money freeing it from the necessity of complying with EU-legislation on electronic money. The design of the Ekhi and the Txantxi, unlike the Eusko, incorporated the system of oxidation to make sure that the currency does not generate accumulation (the currency has a date of expiry).

In none of the three cases is the currency designed to give credit. They are all designed to function in a given territory/community and within a closed network of users. The convertibility rate settled is 1 Eusko/Ekhi/Txantxi $=1$ Euro, that means that for every CCC that you have in circulation you have the equal amount of euros in a safe-deposit box of actual physical notes located in the association/cooperative/town hall.

From this description of the articulation of the CCCs' normative orders with the state laws we observe that in the process of institutionalization, the CCCs achieved to empower themselves in the sense of gaining an institutional space that is recognized by the state and that is oriented to regulate the local economy following their own norms. The way they do this is through the employment of legal strategies permitted by the state, such as signing an agreement for a private money backed by a legal entity (the cooperative, the association and the town hall), with a design of a local money that can only be used within a limited network of users, in a limited territorial community, backed by euros in an account located in a legal entity, supervised by an organ of the entity, contemplating express norms (rules) of functioning and organization of the CCCs. In conclusion, what seems to be technically neutral is, in fact, result of a collective decision of whether to adapt or not the normative order of the CCCs to the normative order of the state.

\subsection{Perception of relationship with the euro}

For the three cases the representatives of the CCCs acknowledged that their currencies are complementary to the official currency. There is a qualitative difference in the CCCs that is not comparable to the system of the euro as also depicted in table 1 previously.

For the Euskal Moneta, the two monetary systems complement each other, but the Eusko have a quality of local empowerment:

For each Eusko in circulation one must have one euro in the account. So Eusko is complementary in that sense, because it does not pretend to substitute the Euro. But, the Eusko is a tool of self-governing of the people, of cooperation, to build the Basque Country that we want, to generate, to create, to give a positive vision. (Copresidents of Eusko)

For the Ekhi, it too is complementary. The use of Ekhis have a quality of local empowerment and of social change:

[O] ur perspective is one of transition, we are not proposing to be an alternative to the system. We want to build a strong network and to imply the Town Hall, the businesses, other associations in the territory, so that at the end we have a network that is isolated from the Euro. Our point is that if you achieved to have a mass of money in Ekhi, then you have the control, because you are the one deciding how the Ekhi should work, with what values, and you do it in a democratic way. The Ekhis are Euros but that we control, they are still euros, and they are legal. The euro is behind the Ekhi but the functioning is different. With social money, you have succeeded in changing habits, and it does not matter for you if that person wants to change the world or not, because by changing habits you change the world. (Representative of Ekhi)

For the Town Hall, the currencies complement, but the Txantxi symbolizes the community and a learning tool: 
The decision to back up the Txantxi in euro was to generate more trust. People are familiar with euros. But the Txantxi has a pedagogical and community value. (Socioeconomy department - Oñati's Town Hall)

Approaching the design of the CCCs from a legal perspective and taking into account the perceptions that the social actors have of their relationship with the euro, I will now analyze the links between the two monetary assets. I can observe, in the three cases, a relationship of complementarity of the CCCs with the euro, in the sense that they are backed by the euro, therefore, they are commensurable and convertible to this supranational currency. Yet, within the complementarity the interviewees identify a "value" reflected in the creation of the distinct normative orders behind the CCCS that is incommensurable, and therefore inconvertible to euros. Therefore, I observe a relation of competition between the euro and the CCCs that is connected with the relationship of simultaneity of two dissimilar normative orders. This observation resembles what J érôme Blanc suggested about plurality of monies, but from a socioeconomic approach. Blanc identifies four binary relations (commensurability, convertibility, co-use and coincidence of spheres of use) that together create four means of linking monies (substitutability, simultaneity, supplementarity, autonomy) that show different links of competition and complementarity, and both can be found together in some cases. So, competition can be present in situations of complementarity, and complementarity can be found in situations of competition. For Jérôme Blanc, the limitation of competition is the "universe of values", which under the socio-legal perspective it would be a variable of the normative dimension of the CCCs.

Following Blanc's typology, the Eusko, the Ekhi and the Txantxi relate to the euro in different ways. They are partially commensurable with the euro, in the sense that they fix their unit of exchange (Eusko, Ekhi, Txantxi) at par with the euro but there are some qualities (like the values) that are incomparable to the other unit of account. So, they are also only partially convertible. Also, there is co-use between the monies, meaning that it is possible to combine the currencies to make a payment. Finally, there is a partial coincidence in the spheres of use, due to the qualitative differences.

According to this socio-economic analysis, the CCCs and the euro compete within complementarity. First of all, they are partially substitutable, this means that (due to the partial commensurability and convertibility) even though is easy to interchange monies it is limited by the symbolic universe (values and moral norms) of the CCCs. From Table 1 it is observed that the Txantxi pursued profit-oriented aims rather than generating a change in the nature of the exchange. In this sense, there is no qualitative differences between the CCCs and the euro, so the currencies were, ultimately, compared quantitatively and therefore in a relationship of strong competition. The Txantxi was more dominated by economic interests and at the end it was highly substitutable with the euro. This may help to explain why, from a socioeconomic approach, the Txantxi failed when members realized it was not meeting the economic expectations of local growth (at that point the symbolic universes became symbiotic) the competition eliminated the Txantxi as the euro was too strong in relation to it. Instead, for the Eusko and the Ekhi the case is different. Their symbolic universes are very different to the euro so that the level of commensurability to the euro is lower. As presented in Table 1, through their normative distinctiveness they manage to create a space of use that differs from the euro and thereby lowers the competition. From the data systematization is revealed that both currencies search a change in the nature of the local economy and exchange relations, by means of equity and social justice. These findings reinforces Blanc's idea that within complementarity the monies are in competition.

Moreover, the CCCs have a relation of quantitative simultaneity and supplementarity with the euro. So, at the moment of payment, users can combine CCCs with euros, within an overlap of spheres of use (those delimited by the symbolic universe of each currency). This means, that they compete quantitatively but they are relatively 
complementary in the symbolic sense (as it as outlined before, the Txantxi less than the Ekhi and the Eusko).

Last but not least, from a combined socio-economic and socio-legal approach we need to consider whether there is room for autonomy within the CCCS. As we said already, the CCCs are partially commensurable with the euro and, thus, partially convertible, so the relationship is of competition in their complementarity. According to the socioeconomic approach, this leads to low economic autonomy, which means that if the currencies were not commensurable, and were clearly separated one from the other, then the CCCs would be more autonomous. In this sense, the researched CCCs have a relationship of low autonomy in relation to the supranational currency, the euro. In the case of the Txantxi, as we explained before, the local currency is in high competition with the euro and is easily substitutable for the euro, because the values and moral norms are similar. This was also observed in the previous sections in relation to the articulation of the two normative orders which revealed the difficulty of the town hall (local state government) to re-direct the normative order of the Txantxi away from the state normative order. Therefore, the Txantxi is highly commensurable (interchangeable) with the supranational currency economically in a way that is also reflected normatively, making it much less autonomous in relation to the euro than the Ekhi and the Eusko. The Ekhi and the Eusko created a normative order that even though it interacts with the state normative order, allowed their normative order to be constantly shaped by the variations of the values, uses and customs of the territorial community through the way the currencies are governed and administrated by the social collective; in such a way that CCCs were valued through a qualitative criterion before the quantitative one. So, the main motivation is not economic but cultural and social. This leads to a more autonomous normative order, in the sense of creating one's own law. As shown in the section 3.3 on the perceptions of the relationship between the CCCs and the community, Eusko clearly opens the dialogue to the different social, economic and political sectors, expanding the participation and public support to the project. Instead, the Ekhi is a more activist project with a clear ideological objective. This may be affecting the expansion of the project in the territory in the sense that the values represented in that normative order are a reflection of a smaller group within the territorial community. Yet, their normative order is very different to the state normative order (and its currency, the euro), so that it keeps the project alive and the community (even quantitatively small) engaged.

In socio-economy, the technical linkages between the CCCs and the state currency leaves the symbolic universe of money to play a major role in the configuration of the autonomy and in limiting the competition between the currencies. In our sociolegal analysis this corresponds to the idea that the normative orders of the CCCs aim to create autonomy, by providing the citizens an institutional space within the state to self-regulate the local economy. It is interesting to notice that from the socioeconomic point of view, more autonomy means less competition within complementarity between the monetary systems, whereas from a socio-legal perspective more normative autonomy may lead to greater normative conflicts through the risk of illegality. So, in the following section we will analyze how these spaces of self-regulation within the state (a situation of complementarity between the normative orders of the state and the CCCs) can contribute to generate more autonomy with limiting competition and without creating risks of conflict.

We can summarize the common grounds and the conflicts between the socioeconomic approach and the socio-legal approach as follows: 
TABLE 2

\begin{tabular}{|c|c|}
\hline \multicolumn{2}{|l|}{ Matrix } \\
\hline $\begin{array}{c}\text { Socio-economic } \\
\text { The symbolic universe }\end{array}$ & $\begin{array}{c}\text { Socio-legal } \\
\text { The normative orders }\end{array}$ \\
\hline Situation 1: & Situation A: \\
\hline Two symbolic universes partially converge & Two normative orders partially converge \\
\hline $\begin{array}{l}\text { (a) } \quad \text { Higher competition between currencies } \\
\text { (CCCs vs national/supranational) }\end{array}$ & $\begin{array}{l}\text { - } \quad \text { Less conflict between normative orders } \\
\text { (CCCs vs state in its different scales) }\end{array}$ \\
\hline - $\quad$ Lower autonomy of CCCs & - $\quad$ Lower autonomy of CCCs \\
\hline Situation 2: & Situation B: \\
\hline $\begin{array}{l}\text { Two symbolic universes (a) and (b) } \\
\text { clearly separated }\end{array}$ & Two normative orders (a) and (b) clearly separated \\
\hline $\begin{array}{l}\qquad(\mathrm{a})\langle\vec{b}(\mathrm{~b}) \\
\text { - } \quad \text { Lower competition between currencies } \\
\text { (CCCs vs national/supranational) }\end{array}$ & $\begin{array}{l}\text { - Higher risks of conflict between normative } \\
\text { orders (CCCs vs state in its different } \\
\text { scales) }\end{array}$ \\
\hline - $\quad$ Higher autonomy of CCCs & - Higher autonomy of CCCs \\
\hline
\end{tabular}

Table 2. Convergence between socio-economic and socio-legal approaches

in relation to autonomy of the social institution of the CCCs.

Source: Own preparation based on researched data.

Following the Table 2, the Txantxi is a case that involved the combination of situation (1) with situation (A), that is, a currency that is very associated with the euro from the point of view of the socio-economy in its symbolic universe. Therefore, the two currencies are very competitive (within the complementarity) and the Txantxi has low autonomy in relation to the supranational currency. From the socio-legal perspective, the Txantxi's normative order and the state normative order converge, and that leads to a situation of less conflict between normative orders, but lower autonomy. Even though the Txantxi created autonomy, this autonomy is low, in the sense that it adapts its normative order to the central-state normative order.

The Ekhi and the Eusko, consist of a combination of situation (2) with situation (A). From the socio-economic perspective, the symbolic universe of the Ekhi and the Eusko are different to the euro, so they are in a relation of lower competition with the euro and are more autonomous than the Txantxi. From a socio-legal perspective, the normative order of the Ekhi and the Eusko converge with the state normative order, leading to less conflict between the two normative orders but also to less autonomy.

\subsection{Perception of relationship with central-state Law}

From the perspective of the state normative order, the legal strategies developed by the CCCs of incorporating into their system institutions and legal provisions from state, ensure a level of validity, security and legitimacy of what is instituted by the CCCs by the social groups/local state government. Yet, from the perspective of the participants of the CCCs, these tactics of adapting its own normative order to some areas of the state normative order, entail also other meanings and reasons.

As regards Euskal Moneta Association they fought to gain a space within the state normative order to self-regulate the economy at a local level:

Our position before the law is very important because our purpose is to become a mass tool. And for us, you can't achieve that if you are outside the law (...). We don't believe that with Eusko we will change the system, so we have chosen everything 
respecting very much the law, or what we know about the law, because when we started in France, there was nothing said on the local currencies. It was not forbidden but it was not legal. (Co-presidents of Euskal Moneta)

They recognize in the state law a way to expand the use of the Eusko. Yet, they recognize it is a relationship of mutual support. It is the state normative order recognizing the activity of the territorial organizations in the local community. In coherence with the legal provisions that the French state created for the CCCs, it is evidence that French state benefits the local normative orders (CCCs) before the supranational normative order (euro):

The government knew that the local currencies were emerging with a lot of strength, and were working very well at community level, so they created the Law on social and solidarity economy (...). Inside the law now we have two little articles on local and complementary currencies, but now we can say that they have legal existence (...). For one, the Eusko is legitimate because we do it in democracy and in association and is a project of general interest. But to have the law is positive, because now more people believe is legal, (Co-presidents of Euskal Moneta)

From the perspective of the Association Ekhi, the lack of state legal recognition and the regulations of the Spanish state affect negatively the functioning of the currency:

The lack of trust in the currency has to do in part with the legislation (...) with papermoney we couldn't grow because people use electronic cards. So, we designed the electronic Ekhi. But then we realized there is a law on electronic money that regulates this type of system, so we decided to stop the project until we get the authorization from the Bank of Spain, so that our projects can comply with all the requisites at a legal level. (Representative of the Ekhi)

In any case, the Ekhi does not directly confront the state but claims to coexist and to function in parallel:

[T] he values of the legality of the currency are very different to the values of the law of the state. The question is, how to move within the system? Well, Goiener is a cooperative that is within the system, complying with all the laws of the system and the normative. Still, it has a way of functioning that is completely different to what the system proposes (...). It is a cooperative, is not a profit-oriented business, and the decisions are taken by the workers.

As for the Txantxi, the interviewees did not point out a conflict with the state law but recognized that the current state regulations limited the effective functioning of the currency. The local state normative order complements the central state normative order, by protecting the local before the supranational:

[T] he problem of the Txantxi is that it was physical money, for electronic money we had to face new regulations. Besides, it is not legal to pay the local taxes or salaries in Txantxis. So, for example, the Town Hall or the cooperatives couldn't pay a part of workers' salaries in Txantxis. (Txantxi's desginer)

This is interesting in relation to the autonomist struggles of the Basque Country against the Spanish State. There are some taxes that the Basque Country collects and administers, but there are some others that it does not. These tax relations between the Basque Country and the state are regulated under the Law 12/2002 (Concierto Económico with the Basque Country). The article 23 about tax on the value of the electric energy production establishes the administration of this tax by the administrations of the state. In fact, Oñati produces its own energy, so under the actual legislation these taxes could not be paid in local currency.

Unlike the Ekhi, the Txantxi did not have legitimacy problems or legal insecurity since the legal support of the project was derived from the institution of the local state government (the Town Hall). It is the state local level supporting the normative order of the currency:

As it was a local project of the Town Hall and the businesses, it was based in mutual trust and in a convention through which the Town Hall is committed to issue and administer the Txantxis, and this is the legal support for the project. (Oñati's Mayor) 


\subsection{Relationships between the CCCs and the central state}

From the descriptions of the legal articulations between the two normative orders and the perceptions that representatives of the CCCs have about their relation with the state law, it is possible to derive a set of relationships between the two normative orders. To begin with, in the three cases the normative orders of CCCs end up being instituted within the state normative order. In the case of the Eusko and the Ekhi, from below and horizontally, the community (activists and citizens) built its normative order and gained legitimacy through the use of its norms by the users in their territory. Its institutionalization enabled the community to participate in the decisionmaking process that defined the internal regulations and its relation with the state normative order. The outcome was different in each case, depending on how the State normative order reacted to these local and collective initiatives.

In the Eusko, the French state normative order recognized the existence of these initiatives and their fundamental role in protecting and keeping the local economy alive, by promoting solidary activities and a social economy that protect the work at local level, and culturally generating activities that link people to the territory. The relationship with the state normative order is subsidiary, because the central state does not reach these areas of the economy that civil society does. Civil society occupies a space (economic, temporal, symbolic, geographical, normative) that the state does not, for different reasons. In this context, the state delegates political and economic power to these territorial organizations that previously activated the terrain articulating different social sectors with common projects like the CCCs. The situation is one of a strong state power but absent from those areas of activity of the CCCs. So, the state is subsidiary in the sense that it does not actively intervene in those areas of the economy in which associations or organizations, guided by the principle of general interest, can do it by themselves. Therefore, the CCCs take control and administer local power and have the acceptance and the approval from the state to develop that role in a certain field of the economy in a given terrain. In this context, the Eusko opted to keep a solid local network with clear internal norms, but also a clear articulation with the state norms, to be inside the system of the state with the benefits and limitations that this implies.

In the case of Ekhi, the Spanish state does not regulate the existence of complementary types of currencies, except as private money among private individuals to be used in a limited network of goods and services. The association adapts its internal regulations to what is in the state law about regulations of money and financial institutions, with the purpose of protecting the project from future risks of illegality. So, the Ekhi within the state system generates its own norms so that they do not directly confront the state normative order. It is not subsidiary because the state does not recognize their role in the local economy and in the community. It is not a relationship of substitutability because the Ekhi does not pretend to replace the law of the state. I will call it co-existence; a relationship by which two normative orders exist at the same time in the same territory without direct confrontation. This implies that one normative order (usually of less power) accepts the existence of the other, incorporating common norms that keep the organization of the society in a harmonious way, through existing institutions (like the contract, the report of approval of the central bank, the legal entity of the cooperative, etc). So, both normative orders function in parallel with certain level of mutual toleration, thereby no direct confrontation. Until the central state does recognize their legal existence (until it does incorporate them to their normative system by means of recognizing their social and economic function at a local level) they will continue developing at the same time, in the same territory, independently the one from the other, without co-operation but simultaneously without conflict.

In the Txantxi, there is a complementary relationship between the CCC and the Spanish State, in the sense that the town hall, promotor and administrator of the Txantxi, ultimately being an extension of the state government, is enhancing the 
functions that the central state is not fulfilling, for different reasons. In fact, what we have seen in the current legislations is that the hierarchy of values of the state normative order prioritizes the protection of the sovereignty of the supranational currency. But this case has the particularity of generating decentralization of the political and economic power at the local level of the state order, by means of incorporating the citizen participation in the process of institutionalization of the CCCs. Therefore, the Txantxi, independently of its failure, demonstrates the ability of local governments to open an institutional space for citizens to create their own norms within the state. So, through the CCCs, local governments can canalize strategies of governance that are de-centralizing. Also, the limit between the local normative order and the state normative order is very slight because it is framed within an institution that forms part of the same state order (the municipality). So, the municipality (state local government) has an extra challenge in re-directing the local normative order away from the state normative order, and this depends on its capacity to open the dialogue with different sectors (specially politically different) and the level of engagement with the general interest of local citizens. The local government, therefore, can provide citizens with an institutional space for developing the CCCs but the success ultimately relies on the citizens' support for the CCCs. A possible socio-legal explanation for the termination of the project Txantxi, in the summer of 2017, could be that the more different the CCCs' normative orders are from the state normative order, the more room there will be for normative and sociological innovation of citizens. This room would be reinforcing the potential of the community's autonomy in creating their own normative order through the social tool of CCCs.

A correlate of the legal articulations is that social collectives achieve self-regulation of the economy at local level. This capacity of self-regulation allows them to promote new rules of the game oriented to generate new habits, but the way they do it is within the match of the rule of law. Besides, the values they promote are linked to the ideological and political aspirations of the social groups that are also aligned with the historical and political background of the territory of the Basque Country and their relationship with the centralist Spanish and French states.

The Spanish Basque Country is an archetype of autonomist struggle before the Spanish State. Organic Law 3/1979 (18 December 1979) on the Statute of Autonomy of the Basque Country establishes conditions of self-governance of the Autonomous Community of the Basque Country (Euskadi) within the Spanish State. The Historical Territories of Álava, Guipúzcoa and Vizcaya confine this autonomous community and in virtue of Art. 3 each of them can create within the state their own institutions of self-government. Art. 6 establishes Euskera as the official language of Euskadi. Under the Law 12/2002 (23 May 2002) of Concierto Económico con la Comunidad Autónoma del País Vasco, the institutions of the historic territories of the Basque Country can establish and regulate their own tax system. The Concierto Económico is a legal instrument to regulate the financial and tax relations between the State General Administration and the Autonomous Community of the Basque Country. This legal instrument was itself a product of a dialogue and negotiation (sometimes of more conflict and sometimes of less conflict) and that dates from the year 1878 with different modifications along the different political context in Spain. There is no space to develop this background here, but we can confirm there is a correspondence between the different articulations of the local-Basque normative order and the central-state normative order with the historic autonomist struggles in the political and economic field.

In France, Euskera does not have official recognition like in Spain. Also, the Basque community is far smaller than in Spain. The Eusko turned out to be more successful (in quantitative terms) in the French Basque Country (Iparralde - North Basque Country) than in the Spanish Basque Country (Hegoalde - South Basque Country). Localism in France is in tension with the strong centralism of the French state. The way the French state diminishes these tensions is through the role of the subsidiary 
state, meaning the state enables room for self-regulation of the communities for the local economies, but within the institutions of the French state. The state creates the Law 856/2014 (31 July 2014) on solidarity and social economy, recognizing the existence of the local currencies and the possibility of local payment services with local currency, under the settled conditions by the state. At the same time, these legal mechanisms allow local communities to self-regulate before the French state, even though this autonomy is low in normative terms considering they are adapting their normative order to the state. In I parralde, citizens took this room to fight for the promotion of the euskera, which represents to them a link of belonging with the territory.

\section{Conclusion: Towards autonomy through CCCs?}

Faced with a social, ecological and economic problem, the social collectives (political activists and citizens) possess the ability to innovate a new social and normative order. Through the CCCs the social actors institute values, uses and purposes, forms of governance and social organization, which are all part of the social representations of the order they seek for society, disputing the meaning and the mainstream use of money in the community/territory. When the use of CCCs is coordinated following the values of its local normative order, the social practice not only is considered valid and legitimate among the participants of that system but also it turns out to be more effective in relation to its functioning.

In any case, these initiatives dispute meanings not only in the practice but also in the state's institutions and especially in the law. The CCCs are created within the framework of the constitutional state. Therefore, the institutionalization of the CCCs is not a lineal process, it has its dialectic, depending on the flexibility of the social collective to articulate the normative order of the territory/community, and depending on its interactions with the state normative order.

From the case studies, the correspondence between the CCCs and the self-regulation of the territorial community appears to be evident. Despite the different relationships between the CCCS and the state, in the three cases, through the CCCs the territorial community succeeded in empowering itself by gaining more institutional room for the self-regulation of the local economy. Autonomy, in Latin, means auto (one-self) and nomos (norm). This indicates that autonomy is the capacity of a person or entity to establish own norms and to let one-self be guided by them when it comes to make a decision. This can be thought in different fields of life: the psychological, the individual, the community, the state, etc. The autonomy varies in a correspondence between the correct understanding (and identification) of the social norms with the self-satisfaction according to one's own norms. Through the CCCs space is opened for all these different levels of autonomy, depending on the individual and community's engagement in instituting these norms, uses and customs (the sources of law). The point is that in all three cases, through different ways and by employing different legal strategies, they achieve more room for autonomy of the communities. From the socio-economic analysis, we get to the same conclusion.

It could be a topic for further research to perform an explanatory research on these relationships of autonomy between the CCCs and the state in its different orders (the local, the national and the supranational). The state renounced to have its own national currency in favor of a common European project (the euro), and in this atmosphere, the local communities claimed their own currencies. Therefore, the economic autonomy reflected in the CCCs at a local level, in contrast to the euro that is supranational, might be reflecting the search for autonomy that the state delegated to the supranational government (the EU). The CCCs could be a local autonomist movement but within state resonance. In this sense, they could be performing what the euro cannot perform at a local level. So, the CCCs might be emerging to locate their own goods, services, workers, cultural production, in an economy that is supranational and with a state that more or less turns its back on the local economies. 
The CCCs might be compensating for that gap in the local economies, in relation to the supranational currency. It is a matter of gaining autonomy in the shadow of the state. Also, it could be for future research to identify which analytical axes reinforce the local autonomy and the citizen participation through the CCCs.

As Ivan Illich stated, the "convivial society" is one that offers human beings the possibility to exercise the most creative and the most autonomous actions, with help of tools less governed by "others". Through CCCs it is possible for communities to innovate beyond the state but within the state, achieving institutional field for autonomy, both normative and economic.

\section{References}

Barber, B., 1977. The Absolutization of the Market: Some notes on how we got from there to here. In: G. Dworkin, G. Bermant and P. Brown, eds., Markets and Morals. Washington, DC: Hemisphere, 15-31.

Bengoetxea, J., 2015. Neil MacCormick y la razón práctica institucional. Lima: Grijley.

Blanc, J., 2016. Unpacking monetary complementarity and competition: a conceptual framework. Cambridge J ournal of Economics [online], 41 (1), 239257. Available from: https://doi.org/10.1093/cje/bew024 [Accessed 30 May 2018].

Blanc, J., and Fare, M., 2013. Understanding the Role of Governments and Administrations in the Implementation of Community and Complementary Currencies. Annals of Public and Cooperative Economics [online], 84 (1), 6381. Available from: https://doi.org/10.1111/apce.12003 [Accessed 30 May 2018].

Bloch, M., 1989. The symbolism of money in Imerina. In: J. Parry and M. Bloch, eds., Money and the Morality of Exchange. New York: Cambridge University Press, pp. 165-190.

Borrello, R., and Plasencia, A., 2010. Las monedas sociales y el debate sobre el origen y las funciones del dinero. Revista de Ciencias Sociales. Segunda época [online], $\mathrm{n}$ o 18, 121-139. Available from:

http://www.unq.edu.ar/advf/documentos/59400c5baa57c. pdf [Accessed 30 May 2018].

Corrons, A., 2015. Monedas complementarias en pro de la sostenibilidad y el desarrollo: enfoque panárquico [online]. Research work, presentation with slides. Máster Interuniversitario en Cooperación al Desarrollo. Universitat Jaume I-Universitat de València / Institut Interuniversitari de Desenvolupament Local. February. Available from: https://www. slideshare. net/gusfrancesc/corrons-af-2015-monedascomplementarias-en-pro-de-la-sostenibilidad-y-el-desarrollo-enfoquepanrquico [Accessed 30 May 2018].

Euskal Moneta - Monnaie Locale du Pays Basque, 2017. Conditions générales d'utilisation de l'Eusko numérique. Adhérent "Particulier" [online]. March. Available from: http://www. euskalmoneta.org/wpcontent/uploads/2017/03/CGU-Particuliers.pdf [Accessed 30 May 2018].

Evans, M.S., 2009. Zelizer's Theory of Money and the Case of Local Currencies. Environment and Planning A: Economy and Space [online], 41 (5), 10261041. Available from: http://journals. sagepub.com/doi/abs/10.1068/a4144 [Accessed 30 May 2018].

Ewald, W., 1997. Comment on Maccormick. Cornell Law Review [online], 82 (5), 1071-1079. Available from: 
https://scholarship.law. cornell.edu/cgi/viewcontent.cgi?article=2704\&context =clr [Accessed 30 May 2018].

Freire, M.V., 2009. Social Economy and Central banks: legal and regulatory issues on social currencies (social money) as a public policy instrument consistent with monetary policy. International Journal of Community Currency Research [online], 13, 76-94. Available from: http://dx. doi.org/10.15133/j.ijccr.2009.007 [Accessed 30 May 2018].

Lietaer, B., 2001. The Future of Money: Creating New Wealth, Work and a Wiser World. London: Century.

Lietaer, B., and Hallsmith, G., 2006. Community Currency Guide [online]. Cabot, VT: Global Community I nitiatives. Available from: https://es.scribd.com/document/28675771/Community-CurrencyGuide\#download\&from_embed [Accessed 30 May 2018].

Lietaer, B., et al., 2012. Money and sustainability, the missing link. A report from the Club of Rome - EU Chapter to Finance Watch and the World Business Academy. $1^{\text {st }}$ ed. Axminster: Triarchy Press.

MacCormick, N., 2007. Institutions of Law: an Essay in Legal Theory. New York: Oxford University Press.

Orzi, R., 2012. Moneda Social y Mercados Solidarios II: La moneda social como lazo social. In: R. Orzi, ed., La moneda social como institución necesaria en la transición. Buenos Aires: CICCUS.

Oszlak, O., 1981. The Historical Formation of the State in Latin America: Some Theoretical and Methodological Guidelines for Its Study. Latin American Research Review [online], 16 (2), 3-32. Available from: http://www.jstor.org/stable/2503123?origin=/STOR-pdf [Accessed 30 May 2018].

Parry, J., 1989. On the moral perils of exchange. In: J. Parry and M. Bloch, eds., Money and the Morality of Exchange. New York: Cambridge University Press, 54-93.

Parry, J., and Bloch, M., 1989. Introduction: Money and the morality of exchange. In: J. Parry and M. Bloch, eds., Money and the Morality of Exchange. New York: Cambridge University Press, 1-33.

Polanyi, K., 1957. Marketless trading in Hammurabi's Time. In: K. Polanyi, C.M. Arensberg and H.W. Pearson, eds., Trade and Market in the Early Empires: Economies in History and Theory. New York: Free Press, 243-270.

Primavera, H., 2001. La moneda social como palanca del nuevo paradigma económico. Red Latinoamericana de Socioeconomía Solidaria [online]. Available from: https://redlases.files.wordpress.com/2008/02/es2001_sintesiscpropuestasmo nedasocial_hp.pdf [Accessed 30 May 2018].

Primavera, H., 2006. Can social money lead to sustainable social innovation? Red Latinoamericana de Socioeconomía Solidaria [online]. Available from: https://redlases.files.wordpress.com/2008/02/en2006_weimarccs_sustainabili ty_hp.pdf [Accessed 30 May 2018].

Sánchez Costa i Larráburu, D., 2012. Monedas locales y ecológicas para la soberanía monetariael derecho a imaginar y desobedecer. Ataques y resistencias / SABC [online], 8. January. Available from: https://ddd.uab.cat/pub/bdsa-arag/bdsa-arag_a2012m1n8/bdsaarag_a2012m1n8p45.pdf [Accessed 30 May 2018].( 
Seyfang, G., and Longhurst, N., 2015. What influences the diffusion of grassroots innovations for sustainability? I nvestigating community currency niches. Technology Analysis \& Strategic Management [online], 28 (1), 1-23; first published 25 July 2015. Available from:

https://doi.org/10.1080/09537325.2015.1063603 [Accessed 30 May 2018].

Tranter, B., 2013. Sampling. In: M. Walter, ed., Social Research Methods. Melbourne: Oxford University Press, 99-118.

Travers, M., 2013. Qualitative Interviewing Methods. In: M. Walter, ed., Social Research Methods. Melbourne: Oxford University Press, 227-253.

Zelizer, V.A., 1989. The Social Meaning of Money: "Special Monies". American J ournal of Sociology [online], 95 (2), 342-377. Available from: https://www.journals. uchicago.edu/doi/10.1086/229272 [Accessed 30 May 2018].

Legal sources

Ayuntamiento de Oñati, 2014. Aprobación inicial de la "Normativa reguladora del Proyecto Elkarri Lagunduz". Boletín Oficial de Gipuzkoa [online], no 232. 4 December. Available from: https://www. oñati.eus/eu/udalaerakundea/ordenantzak/elkarri-lagunduz_bh-bh-iragarkia [Accessed 30 May 2018].

Consolidated version of the Treaty on the Functioning of the European Union - Part Three: Union Policies and Internal Actions - Title VIII: Economic and Monetary Policy - Chapter 2: Monetary policy - Article 128 (ex Article 106 TEC). Official Journal [online], 115, of 9 May 2008. Available from: http://eurlex.europa.eu/legal-content/EN/ALL/?uri=CELEX\%3A12008E128 [Accessed 30 May 2018].

Council [of the European Union] Regulation (EC) No. 974/98 of 3 May 1998, on the introduction of the euro. Official J ournal of the European Communities [online], L 139/1, of 11 May 1998. Available from: http://eurlex.europa.eu/LexUriServ/LexUriServ.do?uri=O] : L: 1998: 139:0001:0005: En:P DF [Accessed 30 May 2018].

Directive 2007/64/EC of the European Parliament and of the Council of 13 November 2007 on payment services in the internal market amending Directives 97/7/EC, 2002/65/EC, 2005/60/EC and 2006/48/EC and repealing Directive 97/5/EC (Text with EEA relevance). Official Journal of the European Union [online], L 319/1, of 13 November 2007. Available from: https://eurlex.europa.eu/legal-content/EN/ALL/? uri=celex: 32007L0064 [Accessed 30 May 2018].

Directive 2009/110/EC of the European Parliament and of the Council of 16 September 2009 on the taking up, pursuit and prudential supervision of the business of electronic money institutions amending Directives 2005/60/EC and 2006/48/EC and repealing Directive 2000/46/EC (Text with EEA relevance). Official J ournal of the European Union [online], L 267/7. 16 September 2009. Available from: https://eur-lex.europa.eu/legalcontent/EN/TXT/?uri=celex: 32009L0110 [Accessed 30 May 2018].

European Commission, n.d. The euro as legal tender [online]. Available from: https://ec.europa.eu/info/business-economy-euro/euro-area/euro/useeuro/euro-legal-tender_en [Accessed 30 May 2018].

Ley 12/2002, de 23 de mayo, por la que se aprueba el Concierto Económico con la Comunidad Autónoma del País Vasco. Boletín Oficial del Estado [online], 124. 25 May 2002. Available from: 
https://www. boe.es/boe/dias/2002/05/24/pdfs/A18617-18636.pdf [Accessed 30 May 2018].

Ley Orgánica 3/1979, de 18 de diciembre, de Estatuto de Autonomía para el País Vasco. Boletín Oficial del Estado [online], 306. 22 December 1979. Available from: https://www.boe.es/boe/dias/1979/12/22/pdfs/A29357-29363.pdf [Accessed 30 May 2018].

Loi no 2014-856 du 31 juillet 2014 relative à l'économie sociale et solidaire. Journal Officiel de la République Française [online], 0176. 1 August 2014. Page 12666, text 2. Available from: https://www. legifrance.gouv.fr/eli/loi/2014/7/31/ERNX1315311L/jo/texte [Accessed 30 May 2018].

Loi $n^{\circ}$ 2016-1321 du 7 octobre 2016 pour une République numérique. Journal Officiel de la République Française [online], 0235. 8 October 2016. Available from:

https://www. legifrance.gouv.fr/affichTexte.do?cidTexte=JORFTEXT000033202 746\&categorieLien=id [Accessed 30 May 2018]. 


\section{Appendix}

Interviews:

Dante Edme-Sanjurjo and Xebax Christy, co-presidents of the Association Euskal Moneta; Bayonne, June 2017.

Miguel Ángel González, representative of the association Ekhi Txanpona; Bilbao, J une 2017.

Mikel Biain, mayor of Oñati Town Hall; Oñati, June 2017.

Ana Martín, councilor for the socio-economic department of Oñati Town Hall; Oñati, June 2017.

Iosu Lizarralde, ex-councilor for the socio-economic department of Oñati Town Hall and designer of the Txantxi; Oñati, June 2017.

I on Turrillas, lawyer-specialist in New Technologies and professor at the University of the Basque Country; San Sebastian, June 2017.

Documents:

Ekhi:

- Cuaderno de Valores Ekhi Txanpona. Available from:

https://vdocuments. $\mathrm{mx} /$ download/b-koadernoa-cuaderno-de-valoresaloreen-k-oadernoa-c-uaderno-d-e-v-alores [Accessed 28 J une 2018].

- Proyecto: versión larga. Una moneda local, social y libre para Bizkaia. Ekhi aldaketa geure esku. Available from:

http://studyres.es/doc/3235315/proyecto-largo---ekhi-txanpona [Accessed 28 J une 2018].

Eusko:

- Règles de fonctionnement, Eusko. Available from:

http://www.euskalmoneta.org/regles-de-fonctionnement-de-leuskstatuo/ [Accessed 24 J une 2018].

- Statuts de l'Association Euskal Moneta - Monnaie locale du Pays Basque. Available from: http://www. euskalmoneta.org/statuts/ [Accessed 24 J une 2018].

- Le Projet Eusko en bref. Available from: http://www.euskalmoneta.org/leprojet/ [Accessed 24 J une 2018].

Txantxi:

- Proyecto Elkarri Lagunduz.

- Plan Especial de Revitalización Comercial de Oñati. 